\title{
The Role of International Institutions (E.G. World Bank) In Co-Financing Public Institutions in Nigeria: Obstacles and Challenges for an Effective and Transparent Procedure.
}

\author{
Lohya Ibrahim Lakai LLB, BL*
}

\begin{abstract}
Nigeria as a state is a member of many international institutions and organizations. Nigeria has also benefited from these institutions particularly financial institutions. For example, the World Bank, International Monetary Fund (IMF) Paris club, The German Development Bank (KWF), African Development Bank, etc. through loans, grants and aid assisted the Nigerian Government in funding some projects and institutions. Despite this funding, Nigeria Institutions continues show little or no impact commensurate to the funding plunged. This work tries to discuss the role of international institutions in co-financing public institutions in Nigeria. In discussing the role of international institutions, the obstacles and challenges for an effective and transparent procedure will be considered as well as proffer solutions to them.
\end{abstract}

\section{A. INTRODUCTION}

States in the international community are like individual human beings who need each other to survive. No state in the world is self-sufficient hence, the need to inter relate and inter depend on each other through trade, collaborations in the area of security, economic development, politics, military equipment and training etc. The interrelations of states have led to the formation of international institutions and organizations. These organizations and institutions are either world, regional, sub regional, multilateral, or continental institutions. They are also specialized institutions eg financial, security, economic or political institutions. Nigeria as a state is a member of many international institutions and organizations. Nigeria has also benefited from these institutions particularly financial institutions. For example, the World Bank, International Monetary Fund (IMF) Paris club, The German Development Bank (KWF),African Development Bank, etc. having, through loans, grants and aid assisted the Nigerian Government in funding some projects and institutions. This work tries to discuss the role of international institutions in co-financing public institutions in $\mathrm{Ni}$ -

* Mrs. Lohya.I. Lakai is a Principal State Counsel in the Plateau State Ministry of Justice, Jos Nigeria. She holds a Bachelor of Laws Degree (LLB) from Ahmadu Bello University Zaria in Nigeria and a Barrister at Law (BL) from the Nigerian Law School, Lagos Campus. She was called to the Nigerian Bar in the year 2008. 
geria. In discussing the role of international institutions, the obstacles and challenges for an effective and transparent procedure will be considered. In discussing this topic, we will try to answer questions like: why has there been little impact despite decades of assistance from financial institutions? The work is divided into six parts: the first is the introduction, the second part deals with the conceptual clarification of terms, the history and types of international financial institutions in the world.

We will also discuss the forms of international financial assistance to Nigeria's public institutions: Official Development Assistance; the Institutional, Procedural and Legal frameworks for the financing of Nigeria's Pubic institutions by international financial institutions; The Nigerian public institutions and financial assistance from the international financial organizations, institutions involved in the use and administration of funds gotten from international institutions; obstacles and challenges in the effective financing of public institutions in Nigeria by international institutions; recommendations for an effective financing of public institutions in Nigeria.

\section{B. CONCEPTUAL CLARIFICATION OF TERMS; THE HISTORY AND TYPES OF INTERNATIONAL FINANCIAL INSTITUTIONS IN THE WORLD}

\section{CONCEPTUAL CLARIFICATION OF TERMS}

There cannot be justice to the topic at hand without the clarification of the meaning of some terms used in the research. Some of these terms are:

1. International Institutions.

2. Public Institutions.

3. Obstacles.

4. Challenges.

5. Developmental Aid.

1. International Institutions: These are organizations established by treaty or other instrument governed by international law and possessing its own international legal personality such as the United Nations, the World Health Organization and Non Atlantic Treaty Organization etc.

2. Public Institutions: Public Institutions means any institutions to which the public are granted access or any class or section of the public are granted access or any building of such institution which is open to the public or any class or section of the public and include any building.

3. Obstacles: This can be define as an obstruction, hindrance, impediment which refer to something, material or non-material that stands in the Way of literal or figurative progress

4. Challenges: These are situation of being faced with something that needs great mental or physical effort in order to be done successfully? 
5. Development Aid: Though the topic at hand talks about the role of international Institutions in co-financing public institutions and not development aid, the act of co-financing institutions through external funds from international institutions qualifies as Foreign Aid or Development Aid. What then is Development Aid? Financial times Lexicon defines development aid as:

"Financial help given by richer countries to poorer ones to help their industrial and economic development".

This definition is too brief as it failed to give other names with which it is called as well as deferential development aid from other aid like religious aid and humanitarian aid.

Wikipidia, a free online search engine defines development aid as follows:

"Development aid (also development assistance, technical assistance, international aid, overseas aid, official development assistance (ODA), or foreign aid) is financial aid given by governments and other agencies to support the economic, environmental, social, and political development of developing countries. It is distinguished from humanitarian aid by focusing on alleviating poverty in the long term, rather than a short term response."

The above definition is self-explanatory and apt for the purpose of this research. This is because it tried to give other names with which Development aid can be called. It also distinguished development aid from other forms of aid like the humanitarian aid.

\section{THE HISTORY AND TYPES OF INTERNATIONAL FINANCIAL INSTITUTIONS IN THE WORLD}

The history of international institutions and organizations is as old as the history of states and international relations. Ever since states were recognized as sovereign entities in the comity of nations, the need to inter relate with other states became indispensable. As states interacted, they created institutions and organizations based on terms agreed by them. The most common international institutions that have existed are: The League of Nations, the United Nations, African Union, European Union etc. Amongst these institutions, and for the purpose of this research, we will only consider the history of institutions that were created in the $20^{\text {th }}$ century particularly the financial institutions since our topic seeks to discuss the funding of Public institutions in Nigeria by international institutions. What are these financial institutions and what then is the history of the Financial Institutions? These institutions can be classified into:

1. Multilateral Development Banks,

2. Bretton Woods Institutions (World Bank and IMF),

3. Regional Development Banks,

4. Bilateral Development Banks and Agencies. 
1. Multilateral Financial Institutions: These are multilateral Development Banks or institutions. They are multilateral as they are created by a group of countries that provides financing and professional advice to other countries for the purpose of development ${ }^{1}$. These have large memberships which include developed donor countries and developing borrower countries $^{2}$. Multi-lateral Financial institutions fund government or Public institutions by way of engaging in projects, issuing loans which can be long-term loans at market rates, very-long-term loans (also known as credits) below market rates, and through grants ${ }^{3}$. These loans or grants are usually tied to conditions agreed upon by the donor institution and the donee. A few examples of these institutions are: World Bank, European Investment Bank (EIB ${ }^{4}$, Islamic Development Bank (IsDB) ${ }^{5}$, Asian Development Bank (ADB) ${ }^{6}$, European Bank for Reconstruction and Development (EBRD) ${ }^{7}$, CAF - Development Bank of Latin America $(\mathrm{CAF})^{8}$, Inter-American Development Bank Group (IDB, IADB) ${ }^{9}$, African Development Bank (AfDB), New Development Bank (NDB), Asian Infrastructure Investment Bank $\left(\mathrm{AIIB}^{10}\right)$ etc.

2. Bretton Woods Institutions (World Bank and International Monetary Fund): These are post world war two financial institutions ${ }^{11}$. Though there may have been some international financial institutions before the Second World War, the history of the present financial Institutions (World Bank and IMF) is traceable to the end of the Second World War ${ }^{12}$. At the end of the Second World War, the economy of Europe was in ruins. This caused the Representatives of the allied states which included some European states (United States, Great Britain, France, Russia, and 40 other countries) to call a United Nations Monetary and Financial Conference, which is known as the Bretton Woods conference ${ }^{13}$. The conference held at Bretton Woods, a resort in New Hampshire, where the world powers laid the foundation for the post-war international financial order ${ }^{14}$. Their aim was to help revamp

1 Multilateral Financial Institutions https://www.investopedia.com/terms/m/multilateral_developme nt_bank.asp accessed on the 16/7/2019.

2 Ibid.

3 Ibid.

4 Ibid.

5 Ibid.

6 Ibid.

7 Ibid.

8 Ibid.

9 Ibid.

10 Ibid. .

11 The world bank and international monetary bank https://www.worldbank.org/en/about/history/theworld-bank-group-and-the-imf accessed 20/7/2019.

12 Sabine Dammasch “The System of Bretton Woods A lesson from History” http://www.ww.uni-ma gdeburg.de/fwwdeka/student/arbeiten/006.pdf.

13 Ibid.

14 Ibid. 
shattered economies of European states as well as create a new system that would prevent another worldwide economic disaster like the Great Depression that destabilized Europe and the United States in the 1930s and had contributed to the rise of Fascism and the $2^{\text {nd }}$ world war ${ }^{15}$. It is the said Bretton woods conference that created the International Monetary Fund (the IMF) and the World Bank ${ }^{16}$. Today as it stands, the international Monetary Fund and the World Bank are the major financial institutions in the world. However, there are many other international institutions that help fund public institutions of states that are in need of funding ${ }^{17}$.

3. Regional Development Banks or Institutions: The regional development banks or institutions have similar functions like the World Bank as they are formed and maintained for the purpose of developing member states but their activities and spread are limited to a region $^{18}$. Shareholders usually consist of the regional countries plus the major donor countries $^{19}$. The best-known of these regional banks cover regions that roughly correspond to United Nations regional groupings, including the Inter-American Development Bank, the Asian Development Bank ${ }^{20}$; the African Development Bank ${ }^{21}$; the Central American Bank for Economic Integration ${ }^{22}$; and the European Bank for Reconstruction and Development ${ }^{23}$ etc.

4. Bilateral Development Banks and Agencies: A Bilateral Development Bank is a financial institution set up by one individual country to finance development projects in a developing country and its emerging market, hence the term bilateral, as opposed to multilate$\mathrm{ral}^{24}$. Examples include: the Netherlands Development Finance Company FMO ${ }^{25}$, headquarters in The Hague; one of the largest bilateral development banks worldwide, the Kretanstalt fur Wiederaufbau (KFW Credit Institution for Reconstruction, founded in 1948, DEG German Investment Corporation or Deutsche Investitions- und Entwicklungsgesellschaft $^{26}$, headquartered in Köln, Germany ${ }^{27}$; the French Development Agency,and Caisse

15 ibid.

16 Ibid.

17 Ibid.

18 IISD SDG Knowledge Hub https://sdg.iisd.org/actors/international-financial-institution/regional-d evelopment-bank/ accessed 20/7/2019.

19 Ibid.

20 Ibid.

21 Ibid.

22 ibid.

23 Ibid.

24 Wikipedia: international financial Institutions: https://en.wikipedia.org/wiki/International_financial institutions accessed on 20/7/2019.

25 Ibid.

26 Ibid.

27 Ibid. 
des dépôts, founded $1816^{28}$, both headquartered in Paris, France, the CDC Group, is a development finance institution owned by the UK Government headquartered in London ${ }^{29}$.

\section{THE FORMS OF INTERNATIONAL FINANCIAL ASSISTANCE TO NIGERIA'S PUBLIC INSTITUTIONS: OFFICIAL DEVELOPMENT ASSISTANCE}

There is no uniform procedure or form through which international financial institutions finance Government institutions in Nigeria however, All funding from international institutions to Nigeria's public institutions are referred to as Official Development Aid (ODA) and They come in the form of ${ }^{30}$ :

I. Direct funding of Budget: Budget Assistance

II. Funding of Projects Programmes through loan, grants and direct partnership with international institutions.

III. Technical Assistance.

IV. Debt Relief

I. Direct Funding of Budget: Budget Assistance: Every Government in the world funds its projects and institutions in line with the provisions of its budget approved for the fiscal year $^{31}$. This then means that any international institution that intends to fund public institutions in Nigeria can do so by assisting in funding the budget or projects captured in the budget $^{32}$. Budget support is a method of financing a recipient country's budget through a transfer of resources from an external financing agency to the recipient government's national treasury ${ }^{33}$. The funds thus transferred are managed in accordance with the recipient's budgetary procedures. Nigeria for a long time has not relied on this source of aid to finance its budget but the recent economic realities has forced Nigeria to consider this. In 2016, Akinwumi Adesina, President of the AFDB, announced that the bank was in the process of finalizing \$1bn worth of budget support, which the bank's board was expected to consider ${ }^{34}$. In May 2016, Nigeria's president Mohammadu Buhari signed the country's largest-ever budget, worth $\$ 30$ bn (now $\$ 19.2 \mathrm{bn}$ ) before the substantial devaluation of the naira, into law ${ }^{35}$. With a planned deficit of $2.2 \mathrm{tn}$ naira $(\$ 7 \mathrm{bn})$, it tripled capital expenditure in hopes of reigni-

29 Ibid.

30 Five official development assistance www.undp.org/.../Inclusive\%20development/.../Towards_Sus tainingMDGProgress_C.accessed on the 20/07/2019.

31 Ibid.

32 Ibid.

33 Ibid.

34 Rummy. E. “ADB Issues Nigeria 1\$ Budget support Lifeline” http://www.publicfinanceinternation al.org/news/2016/09/adb-issues-nigeria-1bn-budget-support-lifeline accessed on the 3/07/2019.

35 Ibid. 
ting the country's flagging economy and averting recession ${ }^{36}$. In the wake of the recession, Nigeria can choose to borrow from world international institutions to finance its budget.

II. Direct Funding of Projects or Programmes through Loans, Grants and Partnership with International Institutions: This is the common way through which international financial institutions fund government institutions and projects. International financial institutions usually have facilities: Loans, Grants, etc which they give to states pursuant to some partnership or agreement reached with the recipient state. These facilities can also be referred to as project facilities or aid. Project aid is aid under which support is provided for a consistent set of activities, with a specified duration and a well-defined objective ${ }^{37}$. Project aid makes available specific capital assets or packages of technical assistance. An important component of project aid consists of infrastructural works, such as roads, harbours, dams, irrigation projects, energy projects, or telecommunications projects ${ }^{38}$. In addition, projects include large-scale and small-scale industrial projects, agricultural projects, integrated rural development projects, education projects, population projects, health projects, projects for women and so forth. Most Aid through International Agencies and Cooperation are project aid $^{39}$. Most of the funding from the International Monetary Fund and the World Bank are project aids. The World Bank and International Monetary fund usually have specific projects, programmes or facilities which for her member states ${ }^{40}$. For example. The IMF has the following facilities for its member states: Stand-By Arrangements (SBA), Extended Fund Facility (EFF), Poverty Reduction and Growth Facility (PRGF), Exogenous Shock Facility (ESF) and Special Drawing Rights (SDR). The World Bank, through grants and project funding has funded the Agricultural sector, energy sector, educational etc ${ }^{41}$.

III. Technical Assistance: This is a form of aid given to less-developed countries like Nigeria by international organizations such as the United Nations (UN) and its agencies, institutions e.t. c. though technical assistance is not monetary, it can be valued as such where the expertise supplied is measured monetarily ${ }^{42}$. The World Bank and International Monetary Fund provide technical assistance to its members ${ }^{43}$. Technical assistance seeks to provide those countries in need with the expertise needed to promote development. Techni-

36 Ibid.

37 Adugna.Abebe. "How much of official development assistance is earmarked?

http://siteresources.worldbank.org/CFPEXT/Resources/CFP_Working_Paper_No2.pdf accessed on the 20/07/2019.

38 Bassey Udo "World Bank approves projects to support Nigeria" June 28, 2018 https://www.premi umtimesng.com/business/274174-world-bank-approves-projects-to-support-nigeria.html accessed on the $20 / 7 / 2019$.

39 Ibid.

40 Ibid.

41 Ibid.

42 Technical Assistance: international Aid https://www.britannica.com/topic/technical-assistance accessed on the $3 / 07 / 2019$.

43 Ibid. 
cal-assistance programs began in earnest after World War II, when much of Europe and Southeast Asia lay in ruins and the countries of Africa and Central and South America were attempting to improve their standards of living. The U.S. president Harry Truman's Point Four Program, announced in 1949, was a notable early example ${ }^{44}$. Technical assistance may involve sending experts into the field to teach skills and to help solve problems in their areas of specialization, such as irrigation, agriculture, fisheries, education, public health, or forestry. Conversely, scholarships, study tours, or seminars in developed countries may be offered, giving individuals from less-developed nations the opportunity to learn special skills that they can apply when they return home. Vocational guidance, management development, business administration, home economics, mathematics, science, accounting, trade skills, urban planning, and legal services are a few of the many areas in which technical assistance has been provided ${ }^{45}$. Many governments furnish technical assistance to depressed urban or rural localities or needy groups within their borders. The largest technical-assistance programs are those administered by the UN and its agencies. They are financed by voluntary contributions from members and concentrate on four major areas: agricultural production, basic-resource surveys and administrative services, health services, and education. In Nigeria, Nigeria has benefited from technical assistance and still benefits from it.

IV. Debt Relief: Debt relief is another form of financial assistance that a nation can get from international institutions. Debt relief involves the waiver of debt of any country on the condition that that debt would be used by the Government to develop its country. A good example of this is the debt relief granted to Nigeria in 2005 on the condition that the Nigerian Government channels the funds for development.

\section{THE INSTITUTIONAL AND LEGAL FRAMEWORKS FOR THE FINANCING OF NIGERIA'S PUBLIC INSTITUTIONS BY INTERNATIONAL FINANCIAL INSTITUTIONS.}

There is no uniform procedure for the financing of Nigeria's public institutions by international organizations. Just like there are many forms of aids or financial assistance to Nigeria, there are also many or different procedures for the financing of Institutions. For example, the procedure the International Monetary Fund (IMF) may choose to assist the Nigerian Institutions may be different from the procedure the World Bank would choose to assist or the African Development Bank may choose to assist the Nigerian Government or United Nations Support Agencies. The International Monetary fund has different packages for a borrowing state and all of these packages are aimed at assisting a country attain a balance of payment in international trade through the stability of its currency as well as the adoption of the structural adjustment Programme of the IMF. These packages may be different from what the African Development bank has for Nigeria or the World Bank has for 
Nigeria. Consequently, we will discuss the different Intentional financial institutions and the various packages they have, in the past had for Nigeria.

\section{THE NIGERIAN PUBLIC INSTITUTIONS AND FINANCIAL ASSISTANCE FROM THE INTERNATIONAL FINANCIAL ORGANIZATIONS.}

Nigeria has enjoyed financial assistance from international financial institutions. This assistance has come in different forms and ways. The major financiers of Nigeria's public institutions and the various kinds of assistance they have given Nigeria are:

1. The Paris Club: debt relief

2. World Bank Assistance

3. International Monetary Fund

4. African Development Bank.

5. United Nations Agencies

1. THE PARIS CLUB AND NIGERIA'S DEBT RELIEF: It would be recalled that Nigeria, as at 2002 , was indebted to $\$ 35.9$ billion with over 85 percent owed to the Paris Club. Nigeria successfully negotiated a Debt Relief Deal with the Paris Club its Creditors in September $2005^{46}$. The Debt Relief Deal resulted in savings (Debt Relief Gains) of about US $\$ 1$ billion per annum to Nigeria. In a pledge to the Paris Club of Debtors on the 23rd of June 2005, Nigeria committed itself to spending the Debt Relief Gains on pro-poor projects and programs in support of a national effort towards the achievement of the Millennium Development Goals (MDGs) ${ }^{47}$ consequently, the Office of the Senior Special Assistant to the President on MDGs (OSSAP-MDG) was created to "guide the resources that would be freed up from the debt deal to MDG-related projects and programmes, whilst at the same time tracking, monitoring and evaluating their progress ${ }^{48}$." The then President Olusegun Obasanjo inaugurated the Presidential Committee on the Assessment and Monitoring of the Millennium Development Goals in Nigeria on 29th June, 2005 and appointed Hajia Amina az-Zubair as the Senior Special Assistant to the President on MDGs ${ }^{49}$.

46 Olabode.Kolawole.Taiwo. "Millennium development Goals in Nigeria: issues and Problems" https://globaljournals.org/GJHSS_Volume14/5-Millennium-Development-Goals.pdf accessed on the $3 / 07 / 2019$.

47 The office of the senior special assistant to the president on Millennium Development Goals www.otiveigbuzor.com/.../A-REVIEW-OF-THE-MANDATE-OF-THE-OFFICE-OF-T... accessed on the $3 / 07 / 2019$.

48 Ibid.

49 Ibid. 
The mandate of the Office of the Senior Special Assistant to the President on MDGs is as follows ${ }^{50}$ :

a) Sensitizing senior public sector managers in collaboration with the Ministry of Finance, Budget Office, Debt Management Office, National Planning Commission and NAPEP in the design and implementation of Virtual Poverty Fund (VPF)

b) Evolve a consultative process meant to identify key strategic areas likely to have the greatest impact on achieving MDGs with the Senior Public Service Managers, representatives of IDPs, the World Bank, DFID, UNDP and Civil Society;

c) Design appropriate systems to tag and track public expenditure line items that will impact on the MDGs at both National and State levels

d) Work in collaboration with the MOF, BOF, NPC and DMO for the operation of a virtual poverty fund designed to effect results from the use of domestic resources derivable from debt relief for poverty eradication programmes;

e) In collaboration with the NPC, design a coherent approach to achieving the MDGs and reporting periodically to the Economic Management Team (EMT);

f) With the support of the NPC, provide quarterly reports to the Presidential Committee on progress and challenges to the delivery of the MDGs nationwide and to provide Secretariat services for the Presidential Committee

g) Assist in revision of sector plans harmonized with NEEDS objectives to achieve the MDGs and incorporate into budget processes accordingly;

h) Develop in collaboration with other agencies in a matching grant mechanism incentives for states to undertake MDGs and set targets for implementation within the framework of their SEEDS;

Any other duties that may be assigned by His Excellency, the President

In order for the Debt Relief savings to contribute more effectively to the achievement of the MDGs, a mechanism for results-oriented expenditure at the State and/or Local Governments, with oversight and coordination from the Federal level, needed to be in place ${ }^{51}$. This would serve to strengthen the relationship among the three-tiers of government so that a proportion of the Federal share of the Debt Relief would be appropriated in the Federal Government Annual Budget as Conditional Grants to States to leverage additional resources and policy reforms at the sub-national level ${ }^{52}$. This need led to the creation of the conditional Grant Scheme. The Conditional Grants Scheme is a programme in which State and Local Governments are availed the opportunity to access funds annually from the Federal Government's share of the Debt Relief Gains ${ }^{53}$. The CGS is contingent on abiding with specific criteria and governing guidelines as outlined in this manual 5. 1.3.2 The Federal Government intervention is by way of making financial grants available to State and Local

50 Ibid.

51 Ibid.

52 Ibid.

53 Ibid. 
Governments in a clearly designed conditional partnership agreement where the States and/or Local Governments contribute equal amounts (i.e. fifty percent from Federal Government Conditional Grants and fifty percent as cash counterpart contribution from the State Government and/or Local Government for the execution of projects in line with the objectives of the MDGs ${ }^{54}$. The CGS is an opportunity to maximize the use of information and expertise at every level of government and share the burden of expenditure responsibility among different levels of government ${ }^{55}$. The scheme also seeks to foster genuine consultations and commitment among the Federal, State, Local Governments, communities and civil society ${ }^{56}$. This will engender sustainability. In addition, the scheme is a unique opportunity to build a platform on which States and Local Governments harmonize their budgets fully with the nations Medium Term Fiscal Framework ${ }^{57}$. Ultimately, it is an opportunity to leverage spending towards supporting State and Local Government programmes that are fully aligned with national policy objectives and the MDGs ${ }^{58}$.

2. WORLD BANK ASSISTANCE: Nigeria became a member of the World Bank shortly after independence. Ever since Nigeria became a member of the Bank, it has enjoyed facilities offered to other remember states ${ }^{59}$. These facilities were available to either the Government or private Sector. Some of these facilities include: The Investment and Development Policy Operations; Banking Products; Trust Funds and Grants; Guarantee; and Non- Lending Facilities. Also worthy of mention and consideration are some special Programmes and Facilities of the World Bank Group to Nigeria's Development. These programmes and facilities are: The International Finance Cooperation - Private Sector Finance and Assistance in Nigeria ${ }^{60}$, Country Assistance Strategy (CAS), 2005 - 2011, Technical Assistance (Ta), The International Development Association (Ida) Support Projects/Schemes, 2004 2011, Multilateral Investment Guarantee Agency (Miga) ${ }^{61}$, The International Centre For

54 Ibid.

55 Ibib.

56 Ibid.

57 Ibib.

58 Ibid.

59 Central Bank of Nigeria: "Understanding Monetary Policy Series No 10: Nigeria's Engagement with Bretton Woods Institutions" https://Www.Cbn.Gov.Ng/Out/2014/Mpd/Understanding\%20mo netary\%20policy\%20series\%20no\%2010.Pdf. Accessed 12/7/2019.

60 This facility/ Programme was designed for the private sector hence, was made available to only the private sector. Through this programme, The International Finance Cooperation was able to finance some private sector activities in Nigeria. Amongst these activities are: Obajana Cement Plc (Manufacturing) in 2003; MTN Nigeria Communications Limited (Telecommunications) in 2003; Microcred Microfinance Bank Nigeria Limited (Small \& Medium Enterprises) in 2011; Guaranty Trust Bank and First Bank of Nigeria Plc (Deposit Money Banks) in 2010. Etc. though this programme is for the private sector, it is relevant ass the growth or otherwise of it.

61 Multilateral Investment Guarantee Agency (Miga): MIGA is the arm of the World Bank Group that helps (foreign) investors and lenders to deal with risks in the local environment by insuring 
Settlement Of Investment Disputes (Icsid) ${ }^{62}$. All these facilities and programmes are designed to promote the macroeconomics of the state hence benefiting to the private and public sector. only three of the facilities are relevant to this research as they involve the direct funding of public institutions. These projects are ${ }^{63}$ :

a) Country Assistance Strategy (CAS), 2005 - 2011,

b) Technical Assistance (TA),

c) The International Development Association (Ida) Support Projects/Schemes, 2004 2011 ,

a) Country Assistance Strategy (CAS), 2005 - 2011): Country Assistance Strategy is a strategy prepared by the World Bank for active borrowers from the International Development Association (IDA) and the International Bank for Reconstruction and Development $(\mathrm{IBRD})^{64}$. This strategy is developed in consultation with country authorities, civil society organizations, development partners, and other stakeholders ${ }^{65}$. The purpose of the CAS is to set out a selective programme of Bank Group support linked to the country's develop-

eligible projects in the host member country against losses relating to: Currency inconvertibility \& transfer Restrictions; Expropriation; War and civil disturbance; Breach of contract; and Non-honoring of sovereign financial obligations. Between 2002 and May 2011, MIGA has guaranteed 13 projects in Nigeria amounting to $\$ 366.55$ million, of which 6 projects $(\$ 148.41 \mathrm{~m})$ are active, 6 projects $(\$ 205.94 \mathrm{~m})$ are on-active, and 1 project $(\$ 12.2 \mathrm{~m})$ was proposed.

62 ICSID is an autonomous and independent international organization of the World Bank Group that came into existence in 1966 following the convention of the Bank. The purpose of the ICSID is to provide facilities for reconciliation and Arbitration of investment disputes between host States and foreign investors in accordance with the provisions of the ICSID Convention. The Convention sought to remove major impediments to the free international flows of private investment posed by non-commercial risks and the absence of specialized international methods for investment dispute settlement. Foreign or international arbitral awards can be enforced in Nigeria under the International Centre for Settlement of Investment Disputes (ICSID). So far, Nigeria has faced two claims at the Centre, namely (i) Shell Nigeria Ultra Deep Limited v. Nigeria's Engagement with Bretton Woods Institution. Federal Republic of Nigeria (ICSID Case No. ARB/07/18) registered on July 26, 2007 on hydrocarbon concession, and (ii) Guadalupe Gas Products Corporation v. Nigeria (ICSID Case No. ARB/78/1) registered on March 20, 1978 on production and marketing of liquefied natural gas.

63 Central Bank of Nigeria: "Understanding Monetary Policy Series No 10: Nigeria's Engagement with Bretton Woods Institutions" https://Www.Cbn.Gov.Ng/Out/2014/Mpd/Understanding\%20mo netary\%20policy\%20series\%20no\%2010.Pdf. Accessed 12/7/2019.

64 The World Bank: THE WORLD BANK IN NIGERIA 1998-2007 Nigeria Country Assistance Evaluation https://documents.worldbank.org/.../100006-PUB-P079737-Nigeria-CAE-Box393 .accessed on the 27/7/2019. See also International Bank for Reconstruction And Development International Development Association International Finance Corporation And Multilateral Investment Guarantee Agency Performance And Learning Review Of The Country Partnership Strategy For The Federal Republic Of Nigeria For The Period FY14-FY17 August 24, 2016 https://docume nts.banquemondiale.org/.../NG-CPS-PRL-August-23-2016-post-SE... accessed on the 12/7/2019.

65 Central Bank of Nigeria "Understanding Monetary Policy Series No 10" Central Bank of Nigeria Nigeria's Engagement With Bretton Woods Institutions https://www.cbn.gov.ng/.../UNDERSTAN DING\%20MONETARY\%20POL... Accessed on the 23/7/2019. 
ment strategy based on comparative advantage in the context of other donor agencies ${ }^{66}$. For Nigeria, the donor country partnership includes the World Bank Group, Department for International Development (DFID), United States Agency for International Development (USAID), and the African Development Bank (AfDB ${ }^{67}$ ). Over 80 per cent of Nigeria's development assistance is obtained from Country Partnership Strategy (CPS). Nigeria benefited from CPS I (2005-09) which was particularly among the World Bank Group and Department for International Development (DFID) and the on-going CPS II spanning 2010-13 aimed at making quality governance an integral part of virtually every form of support ${ }^{68}$.

b) Technical Assistance (Ta): Technical assistance is one of the options or offers of World Bank Group to its members ${ }^{69}$. The World Bank Group, through this assistance, helps member countries in building accountable, efficient public sector institutions, institutional development plans, country-level strategies, and reforms ${ }^{70}$. In addition to the above, the Group provides lending services, advisory services, information and training to member countries so as to deliver on sustainable economic and social improvements. Nigeria is a recipient of Technical Assistance instruments in the areas of the Private Support Project; Micro Small and Medium Enterprises (MSME) Project, and Economic Management Capacity Building Project (EMCAP). Nigeria's engagement with Bretton Woods Institutions.

c) The International Development Association (Ida) Support Projects/Schemes, 2004 2011 IDA is a part of the World Bank Group that helps the world's poorest countries. It complements the World Bank's other lending arm known as the International Bank for Reconstruction and Development (IBRD) which serves middle-income countries with capital investment and advisory services. IDA activities in the country spanned a period of 14 years from 1999 to 2012. Its contribution in Nigeria is in collaboration with other development partners, such DFID, USAID, and AfDB. As at March, 2011, Nigeria was among the top five (5) IDA recipients. Its lending portfolio in Nigeria consists of twenty five (25) active projects with total commitments of US\$3.93 billion in various sectors including agriculture, rural development, education, energy, health, social protection, private sector development and public sector governance ${ }^{71}$.

3. INTERNATIONAL MONETARY FUND: This is an international financial institution that is primarily concerned with ensuring the stability of the international monetary system - the system of exchange rates and international payments that enables countries to transact with one another ${ }^{72}$. It is a voluntary and cooperative institution. It has rules of the Institution, contained in the IMF's Articles of Agreement signed by all members. These rules

66 Ibid.

67 ibid.

68 Ibid.

69 Ibid.

70 Ibid.

71 Ibid.

72 Ibid. 
constitute a Code of Conduct for its members ${ }^{73}$. The code requires members to allow their currency to be exchanged for foreign currencies freely and without restriction. The IMF administers a pool of resources from which members can benefit when they are facing macroeconomic challenges. Nigeria is a beneficiary of this pool of resources however; the resources are usually given to member states upon conditions which include structural adjustments. IMF lending in support of adjustment programme is conditional on the country undertaking certain agreed policy measures. These include:

a) Commitment to implementing specific policies and measures aimed at resolving balance of payments problems, as stipulated in the arrangement between the IMF and borrowing country. Adherence to the commitments is used as performance benchmarks

b) Formulation of an economic programme which underlies the arrangement is done by the country, in consultation with the IMF

The IMFfunds Government Projects and institutions through loans which are technically referred to as facilities. These facilities are in varieties. These facilities have evolved over the years to meet the needs of its members. The duration, repayments terms, and lending conditions attached to facilities vary, reflecting the types of macroeconomic challenges faced by member countries. However, most of the IMF's lending falls into the following six categories. These include: Stand-By Arrangements (SBA), Extended Fund Facility (EFF), Poverty Reduction and Growth Facility (PRGF), Exogenous Shock Facility (ESF) and Special Drawing Rights (SDR).

Apart from these facilities, the Fund also provides a number of support programmes and policy initiatives to member countries including Nigeria. These programmes fall into four broad categories: 1) policy advice, 2) technical assistance, 3) training and, 4) financial support for policies and programmes. The Nigerian Government has enjoyed the support of the IMF through partnership and strategies adopted by parties. Some of these strategies are: the Medium-Term Strategy (MTS) ${ }^{74}$, Poverty Reduction Strategy Papers (PRSPs), Policy Support Instrument (PSI),Surveillance Activities, Structural Adjustment Programme (SAP)

For the purpose of this research, we will discuss the following:

a) Poverty Reduction Strategy Papers (PRSPS)

b) Policy Support Instrument (PSI):

c) Surveillance Activities:

d) Technical Assistance (TA) Projects:

73 Ibid.

74 the Medium-Term Strategy (MTS): The MTS is a blueprint aimed at adapting the institution to the demands of 21st century globalization. It Nigeria's Engagement with Bretton Woods Institutions contains a component focused on capacity-building and technical assistance. The MTS recognizes the crucial role that technical assistance plays in surveillance and the design of IMF lending programmes, as well as helping to rebuild and strengthen institutions in post-conflict countries. However, the MTS also recognizes the need to better define the priorities for technical assistance as it underlines the importance of strengthening the role of recipient countries in designing and implementing technical assistance programmes. 
a. Poverty Reduction Strategy Papers (PRSPS): The PRSPs are prepared by member countries through a participatory process involving domestic stakeholders as well as development partners, including the World Bank and International Monetary Fund. Nigeria's Poverty Reduction Strategy focuses on rapid and sustainable non-oil growth and poverty reduction. The National Economic Empowerment and Development Strategy (NEEDS) was Nigeria's home-grown poverty reduction strategy and medium - term strategy (2003 -2007). This programme was derived from the country's long-term goals of poverty reduction, wealth creation, employment generation and value re-orientation. Updates to the programme were intended at describing the country's macroeconomic, structural, and social policies in support of growth and poverty reduction, as well as associated external financing needs and major sources of financing.

b. Policy Support Instrument (PSI): Policy Support is that assistance that the IMF gives to low-income countries that do not want or need the Fund's financial assistance but seek to consolidate their economic performance. This initiative was introduced in 2005 to support low income countries. It was meant to give the country an upper hand in the decision making process as it was voluntary and demand driven. Specifically, on October 17, 2005, the IMF approved PSI for Nigeria. It was a two-year programme aimed at complementing the NEEDS which focused on rapid and sustainable non-oil growth and poverty reduction. PSI also sends signal to donors, Multilateral Development Banks (MDBs), and financial markets that the country's economic framework is sound and, is intended to pave way for debt cancellation, aid, grants, and better financing terms in capital markets. Members' performance under a PSI is normally reviewed semi-annually, irrespective of the status of the programme. Nigeria's Engagement with Bretton Woods Institutions

c. Surveillance Activities: The IMF identifies risks to global and financial stability through the surveillance of national, regional and global economic developments. Article IV of the IMF Articles of Agreement requires the Fund to undertake regular consultations with each member country on economic conditions and policies. The article commits each member country to pursue policies conducive to the stability of the international monetary system, and global growth and prosperity. Through its consultations, the IMF identifies policy strength and weaknesses and provides advice to members on any necessary corrective measures. Following these consultations, members of staff prepare a report for considerations by the IMF's Executive Board. In majority of cases, the staff report is published, along with a summary of Executive Directors' view as expressed during the Board's discussion.

d. Structural Adjustment Programme (SAP): This was set up by the IMF in March 1986 with a broad objective of helping countries restore and maintain payments viability, while changing the structure of economic activity to achieve high and sustainable rates of economic growth. Under this programme, the concessional resources enable borrowing nations to pursue bolder and longer term reforms that are needed, and the resources available under this facility are highly concessional. In order to reverse the worsening economic fortunes as a result of the collapse of oil price and petroleum output, Nigeria adopted SAP in June 1986 
with emphasis on expenditure reducing and expenditure switching policies as well as using the private sector as the engine of economic growth via commercialization and privatization of government-owned enterprise

e. Technical Assistance (TA) Projects: Technical assistance is meant to boost and update the operations of member Nation's economic institutions to ensure a better working economy by offering high quality, typical and effective technical assistance and support. It also helps in training of staff and designing economic policies necessary for sound macroeconomic and structural policy reforms. Following the banking consolidation, the Fund helped to strengthen the CBN's legal powers to close insolvent banks and advanced the legal processes for establishing Asset Management Corporation of Nigeria (AMCON) to minimize the costs of liquidation. The TA specifically designed a programme to effectively supervise the consolidation of banks. The Fund also extends technical assistance projects to Nigeria Financial Intelligence Unit (NFIU). The project was aimed at strengthening Anti Nigeria's Engagement with Bretton Woods Institutions Money Laundering/Combating the Financing of Terrorism (AML/CFT) supervision in the financial and non-financial sectors; and enhancing the effectiveness and efficiency of the NFIU as well as the conduct of AML/CFT risk assessment in Nigeria.

4. AFRICAN DEVELOPMENT BANK: The African Development Bank (AfDB) is a Bank established for Africa and it is concerned with the promoting the economic development and social progress of its shareholder or member states in Africa ${ }^{75}$. Established in 1964, with Headquarters in Abidjan, Cote d'Ivoire, AfDB is owned by 53 African countries and by 24 countries in the Americas, Europe, and Asia ${ }^{76}$. The AfDB comprises three entities: the African Development Bank (ADB), the African Development Fund (ADF) and the Nigeria Trust Fund (NTF). It is a regional multilateral development finance institution established to contribute to the Economic Development and Social progress of African countries that are the institution's Regional Member Countries (RMCs). AfDB's principal functions include the following 77 :

a) Making loans and equity investments for the economic and social advancement of the regional member countries

b) Providing technical assistance for the preparation and execution of development projects and programs

c) Promoting the investment of public and private capital for development purposes 398 Global Issues for Global Citizens bhar_393_410.qxd 8/14/06 7:50 PM Page 398

75 African development Bank Group http://www.afdb.org/en/about-us/frequently-asked-questions/ Accessed on the 2/8 /2019.

76 Ibid. see also Vinay Bhargava "The Role of the International Financial Institutions in Addressing Global Issues" https://Groupsiteresources.worldbank.org/EXTABOUTUS/Resources/Chapter20.p df accessed on the $2 / 8 / 2019$.

77 Ibid. 
d) Responding to requests for assistance in coordinating the development policies and plans of the regional member countries.

In its operations, AfDB is also required to give special attention to national and multinational projects and programs that promote regional integration ${ }^{78}$. AfDB gets its financial resources from subscribed capital, reserves, funds raised through borrowings, and accumulated net income ${ }^{79}$. Its capital is subscribed such that the regional member countries hold twothirds of the total and the non-regional members one-third. AfDB's highest policy making body is its Board of Governors, which consists of one governor for each member country ${ }^{80}$. The Board of Governors delegates many of its powers to the Board of Directors, which is composed of 18 executive directors: 12 representing the regional members and 6 representing the non-regional members. Under AfDB's founding agreement, its president must be a national of one of the regional members. AfDB lends on a non-concessional basis at a variable lending rate calculated on the basis of the cost of its borrowing. The other terms include a commitment charge of 1 percent and maturities of up to 20 years, including a 5-year grace period. AFDB also provides development finance on concessional terms to its lowincome member countries that are unable to borrow on the above non concessional terms. Money for such loans comes from the 24 non regional shareholders in the form of grant contributions.

5. OTHER AGENCIES OF THE UNITED NATIONS: The United Nations was established for the main purpose of ensuring international peace and security as well as promoting the welfare of member states. Pursuant to the objective of the UN to promote the economic wellbeing of member states, it has established other agencies. These agencies include ${ }^{81}$ : United Nations Industrial Development organization (UNIDO) ${ }^{82}$, the United Nations Children's Fund (UNICEF) ${ }^{83}$, the United Nations Development Programme (UNDP), the United Nations Relief and Works Agency for Palestine Refugees in the Near East (UNRWA) ${ }^{84}$, the World Food Programme (WFP) ${ }^{85}$, the International Labour Organization (ILO) ${ }^{86}$; the Food and Agriculture organization of the United Nations (FAO), the United Nations Educational, Scientific and Cultural Organization $\left(\mathrm{UNESCO}^{87}\right)$, the World Health Organization

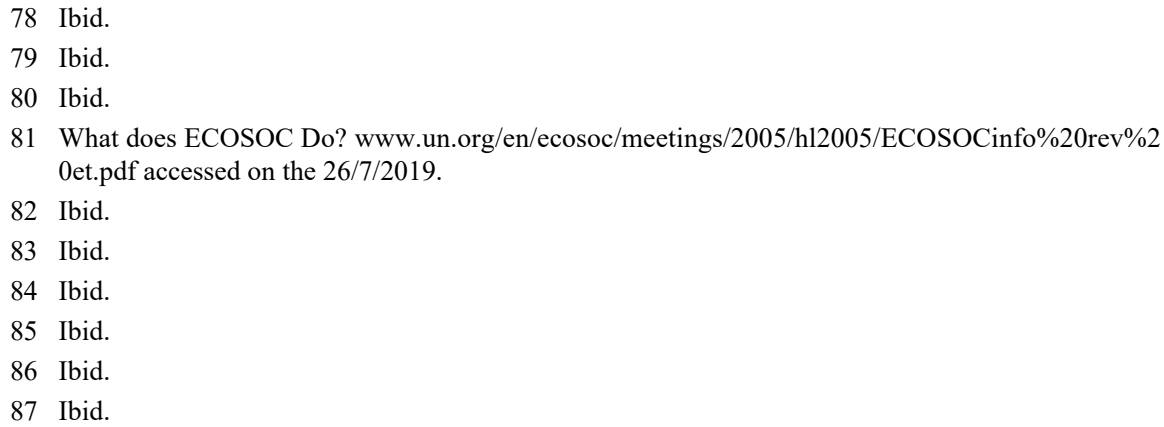


$(\mathrm{WHO})^{88}$, the International Telecommunication Union (LTU) ${ }^{89}$, and the World Meteorological Organization $(\mathrm{WMO})^{90}$.

\section{E. LEGAL FRAMMEWORK AND INSTITUTIONS INVOLVED IN THE USE AND ADMINISTRATION OF FUNDS GOTTEN FROM INTERNATIONAL INSTITUTIONS.}

Funds in whatever forms that accrue to Nigeria either as interest free loans, grants, conditional or concessional loans etc are accessed and applied to government institutions and projects through the following institutions:

I. The Central Bank of Nigeria

II. Ministry of Finance

III. Ministry of Budgeting and The National Planning

IV. National Planning Commission

V. Office of The Senior Special Assistant to The President

VI. Debt Management Office

I. The Central Bank of Nigeria: The Central Bank of Nigeria is the Government's Bank ${ }^{91}$. Consequently, all funds of the Federal Government accruing to the Government are deposited there ${ }^{92}$. The Central Bank also manages the Foreign Exchange/ Exchange rate, currency, and the foreign or external reserve of the country ${ }^{93}$. All funds coming into Nigeria by way of funding from international financial institutions come through the Central Bank and are deposited there ${ }^{94}$. Official Development Assistance from the World Bank, International Monetary Fund and other financial international institutions are accessed through the Central Bank of Nigeria. Other facilities which may not be the direct financial assistance eg. facilities like the Stand-By Arrangements (SBA), Extended Fund Facility (EFF), Exogenous Shock Facility (ESF) and Special Drawing Rights (SDR) all aimed at are ensuring a balance of payment where a country suffers from deficit in its international balance of payment are also beneficial and accessed by the Central Bank of Nigeria.

II. Ministry of Finance: Ministry of Finance is also an important institution that assists in the use and implementation of Official Development Assistance however, the powers and level of involvement of the said ministry only relates to development aid in the form of Concessional Loans. The Ministry of finance would process these loans and make them accessible to the government for use.

91 See section 2 1nd 27 of the central Bank act.

92 Ibid.

93 Ibid.

94 Ibid. 
III. Ministry of Budgeting and The National Planning: The Ministry of Budgeting and National Planning also doubles as the National Planning Commission ${ }^{95}$. It is saddled with the responsibility of harnessing all resources for the purpose of national development. Though the Ministry is fused with the National Planning Commission, it still has its structural differences ${ }^{96}$. The Ministry is divided into departments namely ${ }^{97}$ : Administration, Economic Growth, Finance \& Accounts, Infrastructure, International Cooperation, Macroeconomic Analysis, Monitoring and Evaluation, Social Development, Reform Coordination, Special Duties. For the purpose of this work, only the department of International Cooperation will be X-Rayed. This is because it is the department that is concerned with the access and use of Official Development Assistance. The department of international cooperation is the department that is charged with the duty of managing Multilateral and Bilateral Economic Co-operation including Development Aid and Technical Assistance Programmes ${ }^{98}$. The department is divided into two divisions, namely: Bilateral Economic Cooperation Division; and Multilateral Division ${ }^{99}$. The Multilateral Division on the other hand comprises of three units which are: The United Nations Development System (UNDS); European Union; Commonwealth Desk

a. The United Nation Development System (UNDS) Unit: ${ }^{100}$ This relates and collaborates with the United Nations Development Systems which comprise of the Excom agencies. The Excom agencies include UNDP, UNICEF and UNFPA and other UN agencies.

b. The European Union (EU): Unit is responsible for coordination of all EU supported Programmes/Projects in Nigeria ${ }^{101}$. The Unit is responsible for the administration of EU projects, as well as monitoring of EU Programmes in Nigeria. The source of funding is the European Development Fund (EDF).

c. The Commonwealth Desk: The Commonwealth Desk liaises with the Commonwealth Secretariat and coordinates the technical cooperation activities of the Commonwealth $^{102}$. Nigeria as a member of the commonwealth benefits from her statutory contribution to the funds of the commonwealth especially the Commonwealth Fund for Technical Cooperation (CFTC) ${ }^{103}$.

IV. NATIONAL PLANNING COMMISSION: the national Planning Commission is established by National Planning Commission Act: The National Planning Commission Act is the

95 Ministry of Budgeting and National Planning http://www.nationalplanning.gov.ng/index.php/abo ut-us/depts-units/departments/international-cooperation accessed 27/4/2019.

96 Ibid.

97 Ibid.

98 Ibid.

99 Ibid.

100 Ibid.

101 Ibid.

102 Ibid.

103 Ibid. 
only law enacted by the National Assembly that prescribes the legal framework for the use and application of Official Development Aid. This law, though not enacted for the sole purpose of creating a framework for the administration of Official Development Assistance, has subsumed the administration of Official Development Assistance into the National Development Plan.

The National Planning Commission is established by section 1 of the National Planning Commission Act. The Commission is structured into departments for effective discharge of its functions. Section stipulates its objectives which include ensuring social justice and human welfare at all levels of the Nigerian society; determining how best the Fundamental Objectives and Directive Principles of State Policy in chapter two of the Constitution can achieve the Major Objectives of optimal development etc. Section 3 provides for its membership which include: the Vice President as Chairman, the Deputy Chairman of the Commission, four full time commissioners. Others who are commissioners but not full time commissioners include: The Minister of Finance, the Minister for petroleum resources, the Minister for Agriculture and rural development, the Minister for industry, the Permanent Secretary, State and Local Government Affairs Office, the Governor of the Central Bank of Nigeria, one member to represent the organized private sector, one member to represent the Labour Unions and two other members appointed on their own merit. The functions of the Commission are contained in section 4 of the Act. Section 4(i) of the Act requires the Commission to manage Multilateral and Bilateral Economic Cooperation, including Development Aid and Technical Assistance Programme. In the performance of this function, the Commission shall have the powers to design Official Development Aid policies, advice the president on any policy, monitor the project and implementation of Development Aid policies.

Though the Ministry of Budgeting and National Planning is fused with the National Planning Commission, the latter still maintains its identity as it is only concerned with National Planning. It is the most important and relevant agency that is concerned with Development in Nigeria. It is saddled with the duty of formulating and implementing National Development Plan and Strategy. The Commission is established by section 1 of the National Planning Commission Act. Section 2 prescribes its objectives ${ }^{104}$ The Commission has three Parastatals namely : Centre for Management Development; National Bureau of Statis-

104 Focus on key national development issues and suggest ways for their efficient resolution; Determine how best the Fundamental Objectives and Directive Principles of State Policy contained in the constitution of the Federal Republic of Nigeria 1999 can achieve the major objectives of optimal development and suggest amendments that may be required from time to time, to achieve those objectives in the light of encountered realities; Provide national focal point for the co-ordination and formulation of national policies and programmes; Draw up from time to time national economic priorities and programmes and map out implementation strategies; Co-ordinate the formulation and implementation of government programmes as contained in annual plans, budgets, medium-term and perspective plans at Federal, State and Local Government levels; Enhance the efficiency of public sector spending and general national economic management; Continuously visualize the international economic system in target horizons and identify how best Nigeria can 
tics The Nigerian Institute of Social and Economic Research; The three Parastatals were established to provide services in the areas of research and policies analysis; training of economic managers and supply of statistical information. The Commission has designed development plans for the country. The recent and common of the plans is the NEEDS ${ }^{105}$. This development has enjoyed the support of international financial institutions. All financial support from international institutions were applied towards implementing the NEEDS. Nigeria also through the Commission designed a long term programme which is known as Vision 20:20:20. The National Planning Commission also has a policy on the use of Official Development Assistance ${ }^{106}$. The current ODA policy was formulated in 2007 by the National Planning Commission with the general ODA goals of ${ }^{107}$ : Improving the standard of living of the citizens through poverty reduction programmes and growth enhancement initiatives ${ }^{108}$; Encouraging coordinated inflow of assistance into the national priority sectors as defined in the National Development Framework ${ }^{109}$; Improving national absorptive capacity and effective management of ODA resources; Promoting peace, stability and national unity. The specific goals to be achieved by ODA include : Ensuring the effective use of ODA resources through good governance and complementary public policies; Increasing the national absorptive capacity of ODA with a view to meeting the MDGs and other important global and regional initiatives; Strengthening the institutional capacity of national focal point and Non State Actors involved in the management and implementation of ODA; Integrating ODA into the medium and long term national development framework; Ensuring that ODA creates multiplier effects on the domestic economy; Technology transfer and

best adapt to realize the objectives set out in this section and compete efficiently in the global system.

105 Towards the end of 2003, the National Planning Commission introduced The National Economic Empowerment and Development Strategy (NEEDS) which offered Nigeria an opportunity to experiment with medium-term economic development plan from 2004 to 2007. NEEDS focused "on wealth creation, employment generation, poverty reduction and re-orientating values". These goals were to be released by creating an environment in which business could thrive. Government tried to provide basic services where people were empowered to take advantage of the opportunities which the plan would usher. The federal Government in turn encouraged States and Local Governments to adopt the NEEDS document to suit its peculiar purposes. This gave rise to the equivalent of NEEDS in the states which were called SEEDS meaning (State Economic Empowerment Development Strategy) and in the local governments LEEDS meaning (Local Economic Empowerment Development Strategy). In giving practical expression to the NEEDS programme, the federal government allocated large percentage of capital expenditure to healthcare, education, agriculture, roads, water resources, power and security in the 2004 and 2005 annual budgets.

106 Akpan H. E and Udoma J. A. "Official Development Assistance and Economic Performance in Nigeria, 1970-2010" www.wami-imao.org/sites/default/files/journals/v 12n1_unit5.pdf accessed 3/07/2019.

107 Ibid.

108 Ibid.

109 Ibid. 
development of indigenous technology; Promoting efficient and unified systems for the management of ODA; and Improvement in collaboration between Nigeria and its development partners.

Though the National Planning Commission Act only establishes the National Planning Commission, the Federal Government for administrative Convenience and effectiveness merged the Commission with the National Budgeting and National Planning Commission.

The National Planning Commission still within its policy framework has formulated policy principles for that would guide it in applying official development assistance. These principle are as follows: Involvement of suitably qualified Nigerian professionals and officials in the preparation, formulation and implementation of projects and programmes funded from ODA to ensure ownership and sustainability; Increasing utilization of ODA resources on Technical Assistance (TA) in favour of Nigerian experts; Integration of ODA flows into the national plans and annual budgets; Sensitivity to geopolitical spread of projects and programmes funded from ODA with $50 \%$ of the funding driven by performance criteria so as to stimulate competition between States; Consideration to be given to certain minimum development goals such as where considerable risks exist that some otherwise performing States may be adversely affected by non-performance by other States such as the fight against HIV/AID and immunization of children; Use of transparent and accountable procedures in the procurement of goods and services as may be mutually agreed with Nigeria's development partners; where Nigerian goods are equivalent standard with foreign ones' preference should be given to the made-in-Nigeria goods; Residency for expatriate utilized in the formulation and implementation of ODA programmes and projects shall be for a maximum of twenty-four months at a time. Allowance may be made for a longer time period in case of a complex programme/project; Adequate provision for counterpart funding in the annual budget; Prevention of fraud, corruption and improper diversion of ODA funds through regular Value-For-Money (VFM) audits, reviews, studies and investigations; Sanctions for violation of the rules, regulations, guidelines, procedures and elements of policies stated in this policy document ${ }^{110}$; Evaluation of ODA implementation at all stages should involve Nigerian officials and experts ${ }^{111}$; All project designs for ODA shall be environmentally friendly and indices for measuring such friendliness shall be clearly stated by the proponent ${ }^{112}$; and Involvement of civil society organizations in the implementation and evaluation of ODA projects and programmes ${ }^{113}$

V. Office of the Senior Special Assistant to the President on Millennium Development Goals: The office of the Senior Special Assistant to the President on Millennium Development Goals coordinates debt relief gains as part of Official Development Assistance. It would be recalled that Nigeria, as at 2002 , was indebted to $\$ 35.9$ billion with over 85 
percent owed to the Paris Club. Nigeria successfully negotiated a Debt Relief Deal with the Paris Club of Creditors in September 2005 ${ }^{114}$. The Debt Relief Deal resulted in savings (Debt Relief Gains) of about US\$1 billion per annum to Nigeria ${ }^{115}$. In a pledge to the Paris Club of Debtors on the 23rd of June 2005, Nigeria committed itself to spending the Debt Relief Gains on pro-poor projects and programs in support of a national effort towards the achievement of the Millennium Development Goals (MDGs) consequently ${ }^{116}$, the Office of the Senior Special Assistant to the President on MDGs (OSSAP-MDG) was created to "guide the resources that would be freed up from the debt deal to MDG-related projects and programmes, whilst at the same time tracking, monitoring and evaluating their progress ${ }^{117}$." The then President Olusegun Obasanjo inaugurated the Presidential Committee on the Assessment and Monitoring of the Millennium Development Goals in Nigeria on 29th June, 2005 and appointed Hajia Amina Az-Zubair as the Senior Special Assistant to the President on MDGs ${ }^{118}$.

VI. Debt Management Office: The Debt Management Office is responsible for executing transaction in financial market, including the management of auctions and other forms of borrowing. It is responsible for external debt negotiations, other forms of negotiations and other funding operations.

\section{F. OBSTACLES AND CHALLENGES IN THE EFFECTIVE FINANCING OF PUBLIC INSTITUTIONS IN NIGERIA BY INTERNATIONAL INSTITUTIONS.}

\section{Political Instability and Bad Governance}

Political instability is one of the obstacles to an effective procedure for the financing of public institutions in Nigeria. Nigeria Political Instability and bad governance account for the high level of underdevelopment in Nigeria. Nigeria has experience bad Governance from independence till date. ${ }^{119}$ The government has changed from military to civil or democratic government yet there is little result. What is common to all of them is bad government and excessive looting of public funds. They loot funds with impunity and go scot free, many Nigerians now look forward to occupying public office just to enrich themselves ${ }^{120}$. This has greatly undermined economic development of Nigeria as resources that ought to be

114 The office of the senior special assistant to the president on Millennium development Goals www.otiveigbuzor.com/.../A-REVIEW-OF-THE-MANDATE-OF-THE-OFFICE-OF-T... accessed on the $3 / 07 / 2019$.

115 Ibid.

116 Ibid.

117 Ibid.

118 Ibid.

119 Segun. Adeyeri. "Conflicts and Political Instability in Nigeria: A Critical Discourse" https://www .academia.edu/5450682/conflicts_and_political_instability_in_nigeria_a_critical_discourse_intro duction accessed on the $3 / 8 / 2019$.

120 Ibid. 
used for development (both Official Development Funds and locally generated funds) are looted and miss used. This has affected the confidence that foreign Donors have in the Government and its ability to apply official development fund. The continuous change in Government affected Nigeria's relationship with these International institutions. The worse of it was during the Government of General Sani Abacha ${ }^{121}$. Nigeria was sanctioned by the international institutions and United States. During the period of sanction, there wasn't any support from the International institutions. In fact Nigeria became a Pariah state ${ }^{122}$. This development: political instability affected the inflow of support Nigeria ordinarily would have gotten from international institutions.

\section{Inconsistent Government Policies}

All the world financial international institutions have only help Nigeria subject to Nigeria's adjustment of its structures. The main goal of the adjustment is to reduce the fiscal imbalances of the borrowing country. At the time of Independence, the Nigerian socio economic structure was characterized by Government's Dominance in the economy. Structural Adjustment Programme is a World Bank and International Monetary Fund prescription and pre condition for any financial support. The Structural Adjustment Proramme requires the Government of the day to liberalize the economy by: privatizing Government enterprises, Deregulation, Devaluation of Currency, updating and strengthening its demand management policies; adopting measures that would expand the economy's supply base and encourage domestic production; setting up a new mechanism of realistic exchange rates (in this case, it was the second-tier foreign exchange market); altering the relative prices in order to promote non-oil exports and domestic production, and to improving the efficiency of resource allocation; further rationalizing and restructuring the tariffs to encourage the diversification of the industry; liberating the external trade by dismantling the trade, exchange and price controls; stopping the control of the interest rates; eliminating commodity boards; rationalizing and restructure the enterprises of the public sector; and overhauling the administrative structure of the public sector. The above measures are believed to be short-term solutions to improve the situation with the economy in the long run. These measures have however been very unpopular with the citizenry. Quite a lot of times, the people have protested against these policies. This protest has resulted in the suspension, from time to time of some of the harsh policies. For example, the deregulation of the downstream sector has caused strikes upon strikes. Privatization some Government enterprises eg refineries has been revered. These developments have affected the financial support Nigeria gets from world financial institutions. During the Government of General Abacha, the structural Adjustment programmes were suspended. Foreign exchange was maintained or sustained through the black market. 


\section{The absence of a robust legal and Institutional Framework for use and application of Foreign Aids through funding of Public Institutions.}

Just like it was mentioned earlier, there is no uniform procedure and process through which financial aid or assistance from international institutions is channeled towards the funding of Government institutions. This is because the financing institutions have different policies, programs, and facilities available to borrowing or assisted state. Some of the facilities are in respect of particular projects, particular aspects or sectors of the economy, etc. The funding could also be in the form of debt relief, interest free loans, grants etc. The common procedure of funding Government institutions from funds gotten from international institutions is through injecting the funds in the national development plan of the country. There is no Legislation that will provide a comprehensive plan or procedure for the use and administration of funds from international institutions. The legislation will go a long way in ensuring a good and robust procedure for the co-financing of Nigeria's public institutions.

\section{Corruption}

Corruption appears to be the major problem militating against the efficiency of the funding of international institutions in Nigeria ${ }^{123}$. The World Bank itself has identified corruption as a major problem undermining it efforts in supporting developing economies ${ }^{124}$. Corruption is manifest at almost every level of the process of financing public institutions ${ }^{125}$. Where international institutions release funds for projects, the funds are diverted in to private pockets through the inflation of contracts, the selling of contracts, bribing Government officials to award contracts unqualified companies, use of substandard materials, etc ${ }^{126}$. sometimes nepotism and other considerations come in to affect the efficiency of the applications of these funds. Nigeria has received a lot of funds by way of development aid either through direct transfer or debt relief. At a 2005 meeting in Gleneagles, Scotland, G8 leaders pledged to write off $\$ 40$ billion of poor nations' debts (including Nigeria) and to double aid to Africa (to $\$ 50$ billion) by 2010 . Two years later, at the G8 summit in Heiligendamm, Germany, Chancellor Angela Merkel again placed debt relief and more aid to Africa at the top of the agenda. Nigeria is a beneficiary of debt relief and has received a lot of aid from the development countries basically for the purpose of poverty alleviation yet mismanagement and corruption have undermined the efficiency of development aid.

123 Daniel Kaufmann, "Myths and Realities of

Governance and Corruption" https://siteresources.worldbank.org/.../2-1_Governance_and_Corru ption_K... accessed 3/8/2019.

124 World Bank: Combating Corruption https://www.worldbank.org/en/topic/governance/brief/anti-c orruption accessed on the 3/8/2019.

125 Ibid.

126 Ibid. 


\section{G. RECOMMENDATIONS FOR AN EFFECTIVE FINANCING OF PUBLIC INSTITUTIONS IN NIGERIA}

Having identified the problems militating against the effectiveness of the procedure and process of financing public institutions by international institutions, we hereby consider the areas through which the Government can come up with an effective procedure and process for the co-financing of public institutions in Nigeria. These areas include:

I. Strengthening the Nigerian Financial Intelligence Unit of the Central Bank and Other Anti-Graft Agencies

II. Prioritization of the areas of support by International Institutions.

III. The unification and strengthening of the existing framework for public Institutions financing in Nigeria by International Institutions.

IV. Directly involving the people and Institutions close to the people.

\section{Strengthening The Nigerian Financial Intelligence Unit of the Central Bank And Other Anti-Graft Agencies}

The recent creation of the Nigerian Financial Intelligence Unit as an independent unit ${ }^{127}$ at the central ban is responsible for receiving, requesting, analyzing and disseminating financial intelligence reports and other information to law enforcement agencies, security and intelligence agencies and other relevant authorities is a plus to the war against corruption and particularly to miss-appropriation and misapplication of funds accruing to the Government in the form of official development assistance or development aids and financial assistance meant for the co-financing of public institutions. The Financial Intelligence unit is domiciled at the Central Bank through which the federal Government accesses facilities from international institutions. Henceforth, the financial intelligence Unit will monitor the movement of funds from international Institutions right from the central Bank to other banks up to the final use and application of these funds. Where the funds are diverted or laundered, the unit will keep records and avail such records to relevant anti-graft bodies. The NFIU recently recommended the direct payment of Local Government Funds to Local Government Councils account. This is in a bit to reduce corruption and monitor the spending of these funds.

The Economic and Financial Crimes commission as well as the Independent Corrupt Practices Commission should also be strengthen and they should be encouraged to beam their searchlights on funds coming in as financial assistance or funds designated for co financial public institutions. This will help expose corruption in these areas as well as recommend policies and programmes that will assist in fighting corruption most especially as it relates to funds coming in from international institutions or international financial institutions. 


\section{Prioritization of the Areas of Support by International Institutions}

International financial institutions have in the past, co funded projects and programs in the public and private sectors. In the public sector, all spheres of Government activities have been funded. From health, education, elections, power, agriculture etc. the wide spread of financial aids to almost every sphere of the public sector is evident of the fact that there is no concentration on a particular aspect area. For example, if an international institution is funding agriculture, take for example, if World Bank wants co fund agriculture, it should concentrate its energy and resources on it until result is achieved.

\section{The unification and strengthening of the existing framework for public institutions financing in Nigeria by international institutions.}

There appears to be no uniform procedure or frame work for the use and application of international financial assistance from international institutions. This is because the National Assembly has not seen the need to make an enactment to provide for a unified and robust framework for the application of international financial assistance. A good frame work will provide efficiency of the funds and help curb corruption and misapplication of funds. The frame work will be a product of comprehensive research of the use of international finances. It will be subject to day to day review. The framework will also provide for an assessment, evaluation and monitoring system aimed efficiency.

\section{Directly involving the people and institutions close to the people.}

Most projects and programs undertaken by International institutions are people oriented projects. For example: agricultural projects, health, education etc. these are sectors that affect the populace directly yet most of these partnerships are not entered into directly with the beneficiaries (Local Communities). The World Bank partners more with the federal Government instead of the communities that need these aids directly. Partnering with the relevant communities and local institutions will go a long way cutting cost of implementation, there by maximizing the benefits of the projects. For example, despite the debt relief of 2005 on the condition that the debt will be re injected into the people oriented project, there is little to show for it. The annual money saved from the debt relief was billion dollars. One would expect that there should be projects funded by the fund on every street in Nigeria but it is not the case. Most of these projects are awarded to contractors who inflate the cost of the project, secure the funds, cut off their share. They sometimes give kickbacks to government officials who facilitate these contracts. 